\title{
Is India's 'patent factory' squandering funds?
}

\section{NEW DELHI}

'Patent or perish' is the slogan of Ragunath Mashelkar, head of India's largest publicly funded scientific agency. Over the past decade he has turned the 40 or so labs under his control into a patent factory. "Our labs obtain more patents in the United States than all Indian inventors combined," boasts Mashelkar, who directs the Council of Scientific and Industrial Research (CSIR). "To be noticed, you need a portfolio of patents."

But not everyone is impressed. Critics are accusing the council of wasting taxpayers' money by patenting hundreds of spurious inventions that are never exploited.

The approach of the CSIR has been to file a patent on any new finding that meets the criteria, whether or not the agency wants to commercialize it, says R. K. Gupta, the CSIR's chief of patents. That strategy has certainly been successful in terms of quantity. Between 2002 and 2006, the CSIR was granted 542 US patents more than the total number granted to its counterparts in France, Japan and Germany combined.

But according to Suresh Chandran, who handled biotech patents in India before becoming licensing manager for ES Cell International in Singapore, "Most of the patents are not even worth the paper they are printed on." He points out that each US patent costs the CSIR US $\$ 25,000$ for filing and $\$ 4,000$ a year for maintenance. "Maybe it is a passing phase, but I can tell you that we waste quite a lot on this activity," he says.
One example given by critics is a cow urine extract that the CSIR patented in the United States in 2002, claiming that it enhanced the activity of antibiotics. The claim is yet to be backed by a peer-reviewed publication and the CSIR admits that no drug company has shown interest. "We had a good laugh when we read about it, and that was it," says a spokesman for a leading drug company in New Delhi, who asked not to be named.

Masheklar disputes that the patents are a waste of money, pointing out that a cluster of three US patents on a potential anticancer molecule has been licensed out to an Indian entrepreneur in the United States for around $\$ 100,000$. Considering that only about $3 \%$ of US patents are ever licensed, it is too early for the CSIR to expect big returns, he says.

Critics counter that although the strategy of patenting everything has created awareness among scientists of the potential worth of their discoveries, it is time to ensure that patents create products and wealth, not just statistics. A. V. Rama Rao, former director of the CSIR Indian Institute of Chemical Technology in Hyderabad, wants "A lot of money is going down the drain." the CSIR to set up division to decide which developments are worth patent applications. "A lot of money is going down the drain in the name of patents," he says.

K. S. Jayaraman 